\title{
Effect of Elevated Air Temperature and Carbon Dioxide Levels on Dry Season Irrigated Rice Productivity in Bangladesh
}

\author{
M. Maniruzzaman ${ }^{*}$, J. C. Biswas' ${ }^{1}$ M. B. Hossain ${ }^{1}$, M. M. Haque ${ }^{1}$, U. A. Naher ${ }^{1}$, A. K. Choudhury ${ }^{2}$, \\ S. Akhter², F. Ahmed², R. Sen², S. Ishtiaque'2, M. M. Rahman ${ }^{3}$, N. Kalra4 \\ ${ }^{1}$ Bangladesh Rice Research Institute (BRRI), Gazipur, Bangladesh \\ ${ }^{2}$ Bangladesh Agricultural Research Institute (BARI), Gazipur, Bangladesh \\ ${ }^{3}$ Bangabandhu Sheik Mujibur Rahman Agricultural University (BSMRAU), Gazipur, Bangladesh \\ ${ }^{4}$ Indian Agricultural Research Institute, New Delhi, India \\ Email: ^mzamaniwm@yahoo.com
}

How to cite this paper: Maniruzzaman, M., Biswas, J.C., Hossain, M.B., Haque, M.M., Naher, U.A., Choudhury, A.K., Akhter, S., Ahmed, F., Sen, R., Ishtiaque, S., Rahman, M.M. and Kalra, N. (2018) Effect of Elevated Air Temperature and Carbon Dioxide Levels on Dry Season Irrigated Rice Productivity in Bangladesh. American Journal of Plant Sciences, 9, 1557-1576. https://doi.org/10.4236/ajps.2018.97114

Received: May 2, 2018

Accepted: June 25, 2018

Published: June 28, 2018

Copyright $\odot 2018$ by authors and Scientific Research Publishing Inc. This work is licensed under the Creative Commons Attribution International License (CC BY 4.0).

http://creativecommons.org/licenses/by/4.0/

c) (†) Open Access

\begin{abstract}
Agricultural productivity is affected by air temperature and $\mathrm{CO}_{2}$ concentration. The relationships among grain yields of dry season irrigated rice (Boro) varieties (BRRI dhan28, BRRI dhan29 and BRRI dhan58) with increased temperatures and $\mathrm{CO}_{2}$ concentrations were investigated for futuristic crop management in six regions of Bangladesh using CERES-Rice model (DSSATv4.6). Maximum and minimum temperature increase rates considered were $0^{\circ} \mathrm{C}$, $+1^{\circ} \mathrm{C},+2^{\circ} \mathrm{C},+3^{\circ} \mathrm{C}$ and $+4^{\circ} \mathrm{C}$ and $\mathrm{CO}_{2}$ concentrations were ambient (380), 421 , 538, 670 and $936 \mathrm{ppm}$. At ambient temperature and $\mathrm{CO}_{2}$ concentration, attainable grain yields varied from 6506 to $8076 \mathrm{~kg} \cdot \mathrm{ha}^{-1}$ depending on rice varieties. In general, grain yield reduction would be the highest $(13 \%-23 \%)$ if temperature rises by $4^{\circ} \mathrm{C}$ and growth duration reduction would be $23-33$ days. Grain yield reductions with $1^{\circ} \mathrm{C}, 2^{\circ} \mathrm{C}$ and $3^{\circ} \mathrm{C}$ rise in temperature are likely to be compensated by increased $\mathrm{CO}_{2}$ levels of 421,538 and $670 \mathrm{ppm}$, respectively. In future, the highest reduction in grain yield and growth duration would be in cooler region and the least in warmer saline region of the country. Appropriate adaptive techniques like shifting in planting dates, water and nitrogen fertilizer management would be needed to overcome climate change impacts on rice production.
\end{abstract}

\section{Keywords}

Maximum Temperature, Minimum Temperature, $\mathrm{CO}_{2}$ Levels, Regional Variability, Yield Compensation 


\section{Introduction}

Bangladesh is a deltaic small country in South Asia with the 13th highest world population density and the population would be 202 million by 2050 [1]. All suitable lands are under cultivation, which is decreasing due to increasing demand for residential and industrial uses [2]. Besides, Bangladesh either enjoys food self-sufficiency or scarcity depending on natural calamities that are increasing in recent times [3] [4] [5]. Climate change associated sea level rise is expected to increase the risk for flooding and salinization of agricultural lands, especially near the southern coast [6] [7]. Increase of global mean surface temperatures for 2081-2100 relative to 1986-2005 is projected to be in the range of $0.3^{\circ} \mathrm{C}$ to $4.8^{\circ} \mathrm{C}$ depending on different Representative Concentrate Pathways [8]. Such changes will also be found in Bangladesh where average day temperature increase is likely to be $2.0^{\circ} \mathrm{C}$ to $4.0^{\circ} \mathrm{C}$ by 2100 [8].

Throughout the last 150 years, atmospheric $\mathrm{CO}_{2}$ concentration has increased from 280 ppmv to $385 \mathrm{ppmv}$ in 2008

(https://www.esrl.noaa.gov/gmd/ccgg/trends/) due to widespread human activities such as fossil fuel burning, cement production, and modified land-use patterns [9] [10]. At the current rate of atmospheric $\mathrm{CO}_{2}$ increase it will be double before 2100 causing dramatic effects on global and regional-scale climate. Rainfall has become increasingly variable and has demonstrated an uneven distribution. This erratic pattern produces extreme events, such as floods and drought, which have shown noticeable adverse effects on rice yields [11] [12]. As a result, rice production is likely to decline by $8 \%-17 \%$ by 2050 [13] [14].

Crop agriculture in Bangladesh is dominated by rice monoculture. Almost $80 \%$ of the total cropped area is planted with rice in different seasons, which accounts for more than $90 \%$ of total grain production [15] [16]. Among the rice growing seasons, dry season rice (Boro) contributed more than 53\% of the total rice production in Bangladesh [15]. Food security is synonymous to rice security in Bangladesh. So, there is a crucial need to assess effects of climate change on rice productivity and economic growth of this country.

Some studies have recently investigated the economic effects of climate change on agricultural production in developing countries [17]-[23]. Although these studies showed susceptibility of crop agriculture to climate change, but the limited literatures on these are available for Bangladesh [24] [25] [26] [27] [28]. Ali [26] has discussed the influence of climate change by considering cyclones, storm surges, coastal erosion and backwater effects and reported large land losses in eastern part of Bangladesh because of beach erosion. Rashid \& Islam [28] identified droughts, floods, soil salinity and cyclones as the major extreme climatic events that have affected agricultural production adversely. The CERES-Rice model and the DSSAT model was used to study the influence of higher air temperature and higher atmospheric $\mathrm{CO}_{2}$ concentration on rice yield [29] [30] [31] with old varieties that are not found in the field now a day. Moreover, future climate change scenario delineation has been changed also. There- 
fore, the objective of this study was to assess the impact of climate change on dry season irrigated rice (Boro) production because of high temperatures and $\mathrm{CO}_{2}$ concentrations in Bangladesh for futuristic adoption indication in agriculture.

\section{Materials and Methods}

\subsection{Site Characterization}

The study was conducted in six locations across the country of Bangladesh having diverse soil and weather conditions. The study locations were Gazipur $\left(23^{\circ} 45^{\prime} \mathrm{N}\right.$ latitude, $90^{\circ} 22^{\prime} \mathrm{E}$ longitude, $8.4 \mathrm{~m}$ above mean sea level [AMSL]), Rangpur $\left(24^{\circ} 41^{\prime} \mathrm{N}\right.$ latitude, $89^{\circ} 16^{\prime} \mathrm{E}$ longitude, $33.04 \mathrm{~m}$ AMSL), Rajshahi $\left(24^{\circ} 22^{\prime} \mathrm{N}\right.$ latitude, $88^{\circ} 22^{\prime} \mathrm{E}$ longitude, $\left.17.24 \mathrm{~m} \mathrm{AMSL}\right)$, Barisal $\left(22^{\circ} 41^{\prime} \mathrm{N}\right.$ latitude, $90^{\circ} 21^{\prime} \mathrm{E}$ longitude, $\left.2.54 \mathrm{~m} \mathrm{AMSL}\right)$, Comilla $\left(23^{\circ} 28^{\prime} \mathrm{N}\right.$ latitude, $91^{\circ} 09^{\prime} \mathrm{E}$ longitude, $6.54 \mathrm{~m}$ AMSL) and Habiganj $\left(24^{\circ} 25^{\prime} \mathrm{N}\right.$ latitude, $91^{\circ} 25^{\prime} \mathrm{E}$ longitude, $22.54 \mathrm{~m}$ AMSL) districts of Bangladesh.

\subsection{Model Inputs Parameters}

Selected input data used for CERES-Rice model are shown in Table 1.

\subsubsection{Weather Data}

Weather data for the study regions were collected from the Bangladesh Meteorological Department (BMD) for the period of 1981-2015. Base year daily average (to minimize unusual phenomenon) of maximum and minimum temperatures, rainfall and sunshine hours were calculated and created two successive

Table 1. Selected input data requirements for the CERES-Rice model (modified from [32] [33]).

\begin{tabular}{|c|c|c|}
\hline Agronomic data & Pedological-hydrological data & Daily weather data \\
\hline Sowing and transplanting date & Soil classification & $\begin{array}{l}\text { Maximum and minimum } \\
\text { air temperature }\end{array}$ \\
\hline Row spacing: seeding depth & Texture & Precipitation \\
\hline Number of plants hill ${ }^{-1}$ & Number of layers in soil profile & Solar radiation \\
\hline Number of plants $\mathrm{m}^{-2}$ & Slope & \\
\hline Age of seedling (day) & Permeability & \\
\hline $\begin{array}{l}\text { Base temperature to estimate } \\
\text { phenological stages }\end{array}$ & Drainage & \\
\hline Station information: & Soil layer depth & \\
\hline Latitude & Soil horizon & \\
\hline \multirow[t]{6}{*}{ Longitude } & Clay, silt, and sand content & \\
\hline & Bulk density & \\
\hline & $\begin{array}{l}\text { Saturated hydraulic conductivity } \\
\text { for each soil layer }\end{array}$ & \\
\hline & Total nitrogen for each layer & \\
\hline & Soil $\mathrm{pH}$ for each layer & \\
\hline & Root quantity for each layer & \\
\hline
\end{tabular}


years' weather file for DSSAT format, because Boro rice grows from November in one year and ends at April or May in the next year. The seasonal model simulation was run in SIMMETEO mode for 30 years to capture temperature and $\mathrm{CO}_{2}$ effects on yield and growth duration of selected varieties.

Extreme weather parameters like yearly number of cold spell duration indicator by taking annual count of days with at least 6 consecutive days when minimum temperature $\left(<10^{\text {th }}\right.$ percentile) and number of warm spell indicator by taking annual count of days with at least 6 consecutive days when maximum temperature $\left(>90^{\text {th }}\right.$ percentile) was estimated by using RClimDex v1.0 model software [34]. These indicators stated the cooler or warmer events of a particular area over the time spell.

\subsubsection{Soil Parameters}

Location-wise soil parameters used in DSSATv4.6 model is thickness of three layers, layer-wise sand, clay, bulk density, soil organic carbon and soil hydraulic characters. Soil pH, EC and slope also are required as inputs for different locations (Table 2). The terms "lower limit" and "drained upper limit" correspond to the permanent wilting point and field capacity, respectively [35].

\subsubsection{Crop Parameters}

BRRI dhan28, BRRI dhan29 and BRRI dhan58 were used for grain yield and growth duration under varying levels of increased temperatures and $\mathrm{CO}_{2}$ concentrations. In all locations, selected varieties were tested against 15 November sowing, the optimum sowing date for Boro rice cultivation. In sowing date experiment, seeds were sown on 15 October to 30 December at 7 days interval to find out the optimum sowing date and to overcome the climatic effects for Boro rice growing.

Table 2. Physical and chemical properties of soils at the selected locations.

\begin{tabular}{|c|c|c|c|c|c|c|c|c|c|c|c|c|c|c|c|c|c|c|}
\hline \multirow{2}{*}{$\begin{array}{c}\text { Attributes } \\
\text { Soil depth }(\mathrm{cm})\end{array}$} & \multicolumn{3}{|c|}{ Gazipur } & \multicolumn{3}{|c|}{ Rangpur } & \multicolumn{3}{|c|}{ Rajshahi } & \multicolumn{3}{|c|}{ Barisal } & \multicolumn{3}{|c|}{ Comilla } & \multicolumn{3}{|c|}{ Habiganj } \\
\hline & 20 & 40 & 60 & 20 & 40 & 60 & 20 & 40 & 60 & 20 & 40 & 60 & 20 & 40 & 60 & 20 & 40 & 60 \\
\hline WP (vol., frac.) & 0.29 & 0.29 & 0.28 & 0.09 & 0.08 & 0.06 & 0.23 & 0.17 & 0.15 & 0.24 & 0.24 & 0.22 & 0.26 & 0.25 & 0.24 & 0.26 & 0.25 & 0.24 \\
\hline FC (vol., frac.) & 0.45 & 0.43 & 0.40 & 0.28 & 0.22 & 0.26 & 0.41 & 0.35 & 0.35 & 0.44 & 0.44 & 0.44 & 0.41 & 0.39 & 0.38 & 0.41 & 0.39 & 0.39 \\
\hline Porosity (vol., frac.) & 0.50 & 0.50 & 0.49 & 0.48 & 0.46 & 0.40 & 0.48 & 0.49 & 0.44 & 0.49 & 0.48 & 0.48 & 0.46 & 0.47 & 0.47 & 0.46 & 0.47 & 0.47 \\
\hline $\mathrm{Ks}(\mathrm{cm} / \mathrm{hr})$ & 0.32 & 0.35 & 0.32 & 1.10 & 0.89 & 0.81 & 0.15 & 0.48 & 0.48 & 0.15 & 0.14 & 0.14 & 0.17 & 0.19 & 0.19 & 0.29 & 0.21 & 0.19 \\
\hline $\mathrm{BD}(\mathrm{g} / \mathrm{cc})$ & 1.35 & 1.34 & 1.35 & 1.39 & 1.41 & 1.52 & 1.29 & 1.42 & 1.42 & 1.26 & 1.30 & 1.31 & 1.36 & 1.35 & 1.35 & 1.34 & 1.35 & 1.35 \\
\hline $\mathrm{OC}(\%)$ & 0.72 & 0.60 & 0.38 & 0.45 & 0.37 & 0.20 & 1.18 & 1.10 & 0.90 & 0.90 & 0.70 & 0.40 & 0.54 & 0.31 & 0.29 & 0.74 & 0.31 & 0.21 \\
\hline Clay (\%) & 48.0 & 48.0 & 47.0 & 17.0 & 8.0 & 5.0 & 60.0 & 35.0 & 37.0 & 34.0 & 36.0 & 34.0 & 46.0 & 44.0 & 42.0 & 45.0 & 44.0 & 42.0 \\
\hline Total N (\%) & 0.07 & 0.06 & 0.04 & 0.04 & 0.03 & 0.02 & 0.15 & 0.12 & 0.10 & 0.09 & 0.07 & 0.04 & 0.05 & 0.03 & 0.03 & 0.07 & 0.03 & 0.02 \\
\hline $\mathrm{pH}$ & 6.4 & 6.3 & 6.2 & 5.5 & 5.9 & 6.1 & 5.6 & 6.0 & 6.2 & 7.5 & 7.0 & 6.8 & 6.7 & 7.0 & 7.3 & 6.6 & 7.0 & 7.2 \\
\hline
\end{tabular}

${ }^{\star}$ WP-Wilting point, FC-field capacity, Ks-Saturated hydraulic conductivity, BD-Bulk density, OC-Organic carbon. 


\subsection{Yield Simulations}

Potential yield is defined as the maximum yield of a variety restricted only by season-specific climatic conditions. This assumes that other inputs (nutrient, water, etc.) are non-limiting and cultural practices are optimal. Thus, the potential yield of a crop depends on the temporal variation in $\mathrm{CO}_{2}$ level in the atmosphere, solar radiation, maximum and minimum temperatures during the crop growing season and physiological characteristics of the variety. Mechanistic crop growth models are routinely used to estimate potential yield and assess the effects of climate change [36] [37] [38] [39].

To simulate potential rice yield CERES-Rice v4.6 was used. This mechanistic model simulates crop growth and development processes, net photosynthesis based on radiation use efficiency, leaf area index, extinction coefficient and light absorption by the canopy [40]. The model can also simulate the effect of $\mathrm{CO}_{2}$ on photosynthesis and water use based on stomatal conductivity [41].

Potential yields of BRRI dhan28, BRRI dhan 29 and BRRI dhan58, the most popular varieties in dry season of Bangladesh, were simulated. Genetic coefficients used for those varieties are provided in Table 3 . The coefficients were determined based on experiments by repeated iterations until a close match between simulated and observed phenology and yield was obtained. The data of field experiments were used for calibration and validation. There was a good agreement between simulated and observed phonological development and grain yield. The performance of the model has been well validated in Bangladesh [42].

\subsection{Selection of Scenarios for Model Applications}

In future, the rise in temperature is likely to be $2^{\circ} \mathrm{C}$ to $4^{\circ} \mathrm{C}$ by 2100 in South Asia including Bangladesh [8]. So, the CERES-Rice model was applied for normal (no temperature rise) and $1^{\circ} \mathrm{C}, 2^{\circ} \mathrm{C}, 3^{\circ} \mathrm{C}$ and $4^{\circ} \mathrm{C}$ rise over normal weather condition.

Table 3. Genetic coefficients of rice varieties used in DSSAT model.

\begin{tabular}{cccc}
\hline \multirow{2}{*}{ Genetic coefficient parameters } & \multicolumn{3}{c}{ Values } \\
\cline { 2 - 4 } & BRRI dhan28 & BRRI dhan29 & BRRI dhan58 \\
\hline $\begin{array}{c}\text { Juvenile phase coefficient (P1), GDD } \\
\text { Photoperiodism coefficient (P2R), }\end{array}$ & 825 & 950 & 850 \\
GDD h ${ }^{-1}$ & 150 & 150 & 150 \\
Grain filling duration & & & \\
coefficient (P5), GDD & 425 & 550 & 470 \\
$\begin{array}{c}\text { Critical photoperiod (P20), h } \\
\text { Spikelet number coefficient (G1) }\end{array}$ & 12.6 & 12.8 & 12.7 \\
Single grain weight (G2), g & 50 & 60 & 55 \\
Tillering coefficient (G3) & 0.022 & 0.021 & 0.021 \\
Temperature tolerance coefficient (G4) & 1.0 & 1.0 & 1.0 \\
\hline
\end{tabular}

${ }^{\mathrm{a}} \mathrm{GDD}$, growing degree days $\left({ }^{\circ} \mathrm{C}\right)$. 
During initial growth stage, Boro rice plants grow under cool and dry conditions but exposed to hot environment in flowering and harvesting stages. Although Boro rice growing season is generally uneventful, few localized thunder showers take place sometimes. It is found that temperature stress and resultant crop damage is a significant reason for reductions in Boro rice yield, especially with delayed established crop. According to CMIP5 and Earth System Model, predicted $\mathrm{CO}_{2}$ concentrations will be reaching $421 \mathrm{ppm}$ (RCP2.6), $538 \mathrm{ppm}$ (RCP4.5), 670 ppm (RCP6.0), and 936 ppm (RCP 8.5) by the year 2100 [8]. So, we have selected those $\mathrm{CO}_{2}$ levels and compared with ambient $\mathrm{CO}_{2}$ concentration (380 ppm).

\section{Results and Discussion}

\subsection{Grain Yields}

Grain yields of selected rice varieties varied among regions mainly due to climatic variability and soil properties. In general, the highest potential grain yield was found in Rangpur and the lowest in Barisal region irrespective of varieties. Grain yield varied from 6.50 to $7.36,7.29$ to 8.08 and 6.84 to $7.80 \mathrm{t} \cdot \mathrm{ha}^{-1}$ for BRRI dhan28, BRRI dhan29 and BRRI dhan58, respectively based on long-term (1981-2015) weather parameters (Figure 1). These variations are related with weather parameters and soil properties. Pathak [43] reported 7.7 to $10.7 \mathrm{t} \cdot \mathrm{ha}^{-1}$ yield of wet season rice in Indo-Gangetic Plains (IGP). Aggarwal et al. [39] reported about $10 \mathrm{t} \cdot \mathrm{ha}^{-1}$ rice yields in Punjub and Haryana. Mohandas et al. [44] also reported $10.5 \mathrm{t} \cdot \mathrm{ha}^{-1}$ potential yield in Kapurthala district, Punjab but 7.1 $\mathrm{t} \cdot \mathrm{ha}^{-1}$ in Cuttack, Orissa. These clearly indicate that grain yield of rice varies across locations.

\subsection{Weather Data and Its Extremes}

Long-term (1981-2015) monthly mean weather data showed that mean maximum temperature varied from $23.0^{\circ} \mathrm{C}$ to $36.1^{\circ} \mathrm{C}$ for all the study regions. The

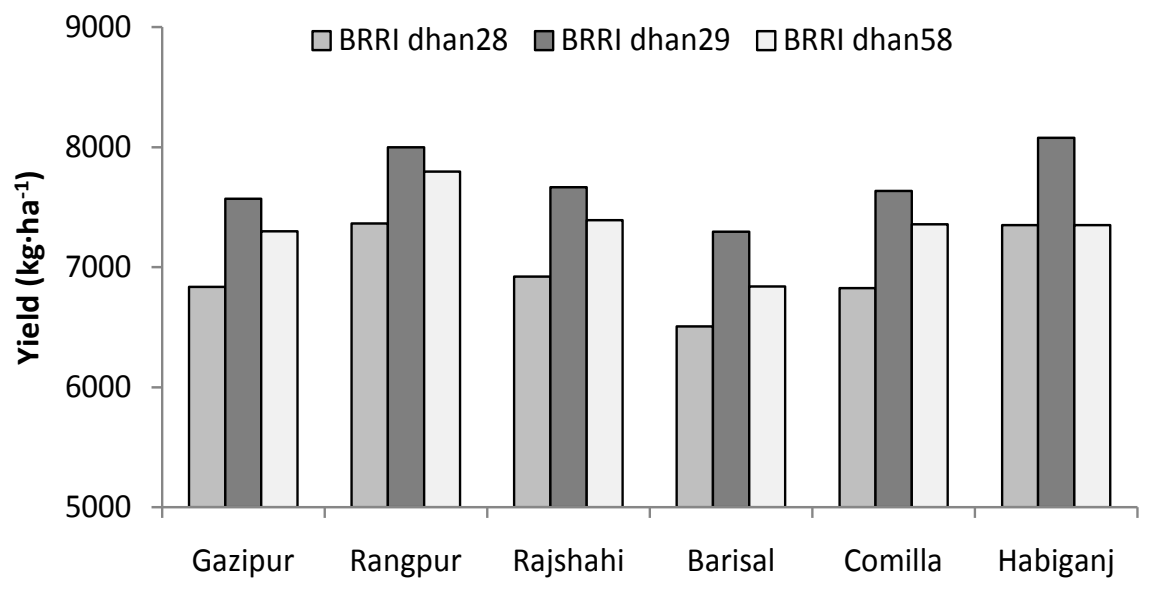

Figure 1. Grain yields of selected varieties under normalized weather conditions in different regions of Bangladesh. 
lowest mean maximum temperature was found in January and the highest mean maximum temperature in April (Figure 2). The extreme high temperature $\left(>35^{\circ} \mathrm{C}\right)$ was recorded at Rajshahi location. Long-term mean minimum temperature varied from $10.4^{\circ} \mathrm{C}$ to $25.0^{\circ} \mathrm{C}$. The lowest temperature was found at Rajshahi in January and the highest temperature at Barisal in May (Figure 2).

Climatic extreme events like five years' total number of cold spell duration were in decreasing trends in most of the regions, except a slight deviation in Rangpur and Rajshahi areas (Table 4), where cold spell was decreasing in 1996-2000 and then in increasing trend. Five years total number of warm spell duration was in increasing trends in most cases except in Rangpur region (Table 4). Since trend in warm spell is increasing, Boro rice crop might be exposed to unusual temperature in future and thus reduced production is most likely. Boro rice starts its journey in cooler and drier conditions and continue grow up to vegetative. Its flowering, ripening and harvesting stages are exposed to hot summer weather. So, Boro rice faces winter extreme cool and warm spells in its growing periods. Initially crop growth is hampered because of cold spell, but temperature is increasing in most regions and if temperature goes beyond $35^{\circ} \mathrm{C}$ during heading and flowering stages, sterility increased resulting in reduced grain yield. Generally, any temperature below $20^{\circ} \mathrm{C}$ and above $30^{\circ} \mathrm{C}$ cause yield reduction in rice [45]. Horie et al. [46] also reported that as the average temperature increases above $22^{\circ} \mathrm{C}-23^{\circ} \mathrm{C}$, rice yield declined linearly up to $30^{\circ} \mathrm{C}$ and decline sharply thereafter. The initial linear decrease was due to the shorter crop
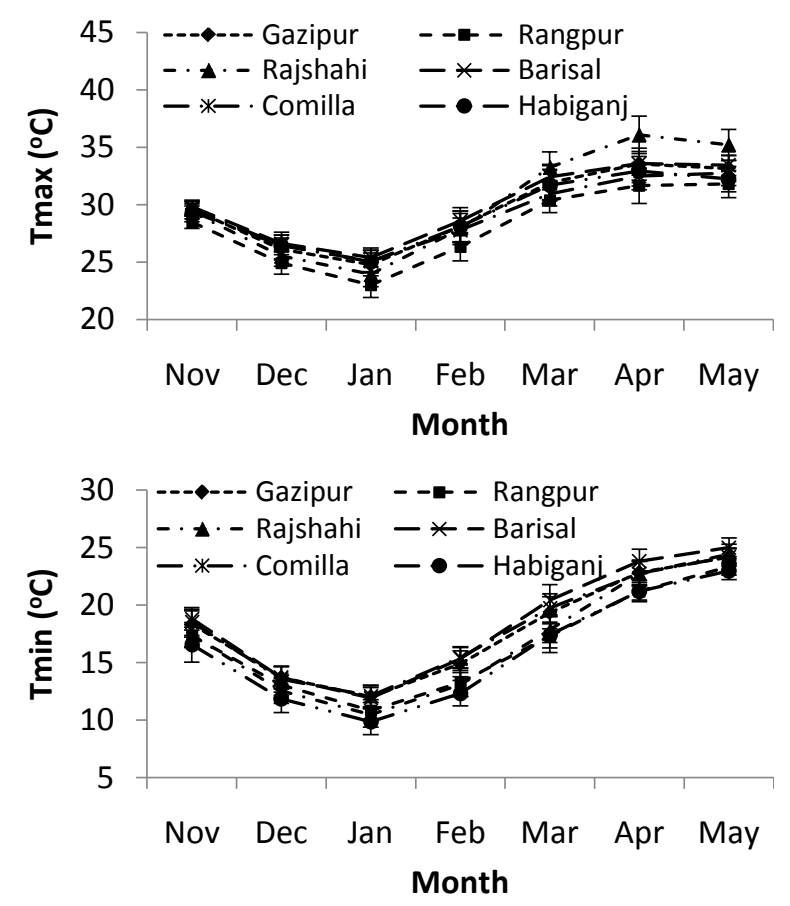

Figure 2. Long-term (1981-2015) monthly mean maximum and minimum temperature of the study regions during winter season. Error bar indicate the standard deviation. 
Table 4. Number of cold and warm spells duration during 1981 to 2015 in the study regions of Bangladesh.

\begin{tabular}{|c|c|c|c|c|c|c|c|c|c|c|c|c|}
\hline \multirow[b]{2}{*}{ Year } & \multicolumn{2}{|c|}{ Gazipur } & \multicolumn{2}{|c|}{ Rangpur } & \multicolumn{2}{|c|}{ Rajshahi } & \multicolumn{2}{|c|}{ Barisal } & \multicolumn{2}{|c|}{ Comilla } & \multicolumn{2}{|c|}{ Habiganj } \\
\hline & $\begin{array}{c}\text { Cold } \\
\text { spell (d) }\end{array}$ & $\begin{array}{c}\text { Warm } \\
\text { spell (d) }\end{array}$ & $\begin{array}{c}\text { Cold } \\
\text { spell (d) }\end{array}$ & $\begin{array}{c}\text { Warm } \\
\text { spell (d) }\end{array}$ & $\begin{array}{c}\text { Cold } \\
\text { spell (d) }\end{array}$ & $\begin{array}{c}\text { Warm } \\
\text { spell (d) }\end{array}$ & $\begin{array}{c}\text { Cold } \\
\text { spell (d) }\end{array}$ & $\begin{array}{c}\text { Warm } \\
\text { spell (d) }\end{array}$ & $\begin{array}{c}\text { Cold } \\
\text { spell (d) }\end{array}$ & $\begin{array}{c}\text { Warm } \\
\text { spell (d) }\end{array}$ & $\begin{array}{c}\text { Cold } \\
\text { spell (d) }\end{array}$ & $\begin{array}{c}\text { Warm } \\
\text { spell (d) }\end{array}$ \\
\hline $1981-85$ & 0 & 19 & 0 & 6 & 17 & 21 & 27 & 27 & 23 & 13 & 21 & 0 \\
\hline $1986-90$ & 7 & 60 & 19 & 18 & 31 & 60 & 8 & 14 & 12 & 13 & 40 & 12 \\
\hline 1991-95 & 7 & 31 & 43 & 8 & 23 & 40 & 25 & 7 & 58 & 7 & 41 & 13 \\
\hline 1996-00 & 7 & 44 & 8 & 32 & 6 & 38 & 32 & 29 & 26 & 27 & 7 & 75 \\
\hline 2001-05 & 0 & 20 & 12 & 7 & 12 & 42 & 0 & 6 & 0 & 28 & 0 & 51 \\
\hline 2006-10 & 6 & 32 & 15 & 0 & 30 & 50 & 20 & 27 & 6 & 26 & 12 & 96 \\
\hline 2011-15 & 0 & 44 & 40 & 7 & 22 & 71 & 7 & 38 & 0 & 18 & 0 & 79 \\
\hline
\end{tabular}

duration caused by increased temperature and the sharp decline after $30^{\circ} \mathrm{C}$ was because of spikelet sterility from high temperature damage.

\subsection{Effect of $\mathrm{CO}_{2}$ and Temperature on Yield}

Grain yields decreased with increase in temperatures at 380, 421, 538, 670 and 936 ppm $\mathrm{CO}_{2}$ levels; although it improved with increasing $\mathrm{CO}_{2}$ levels for a specific temperature rise (Figures 3-5). Increase in grain yields were $2.6 \%-2.8 \%$ for RCPs 2.6, 10.8\% - 11.8\% for RCPs 4.5 and 19.4\% - 21.2\% for RCPs 6.0 and $32.7 \%-37.1 \%$ for RCPs 8.5 with varied $\mathrm{CO}_{2}$ levels. The highest yield increase was $40.3 \%$ with BRRI dhan $28,33.6 \%$ with BRRI dhan 29 and $40.3 \%$ with BRRI dhan58 rice varieties at $936 \mathrm{ppm} \mathrm{CO}_{2}$. In all regions of Bangladesh, predicted mean yield reduction was $4.77 \%, 3.44 \%$ and $5.03 \%$ per degree rise in temperature for BRRI dhan28, BRRI dhan29 and BRRI dhan58, respectively at $380 \mathrm{ppm}$ $\mathrm{CO}_{2}$ level. Mahmood [24] reported 9.7\% - 22.7\% yield reduction at Mymensingh and $7.3 \%-17.0 \%$ at Barisal with BR3 depending on temperature rise. This indicates that rice production will be in decreasing trends in future if climate smart practices are not adopted. Grain yield reduction rates were higher with short and medium growth duration rice varieties compared to long duration BRRI dhan29. Among the study studied regions, grain yield reductions were the lowest $(0.7 \%$ $16.4 \%$ ) in Barisal irrespective of temperature rise with all the tested varieties and $\mathrm{CO}_{2}$ levels (Tables 6-8). Since minimum temperature range is generally higher in Barisal regions during Boro season (Figure 2), attainable yield is low (Figure 1) compare to other tested regions and thus less grain yield reduction is likely because of temperature rise in future. Long duration variety (BRRI dhan29) had the lowest grain reduction $(12.2 \%$ - 15.4\%) compared to other tested varieties irrespective of regions and $\mathrm{CO}_{2}$ levels (Tables 6-8). Crop duration reduces with increased temperature, but its influence is more prominent with short duration variety. So, higher grain yield is expected in future with existing long duration varieties than others. The scenario could be changed in future with the development of cool variety. In Rangpur region, grain yield reduction with BRRI dhan29 

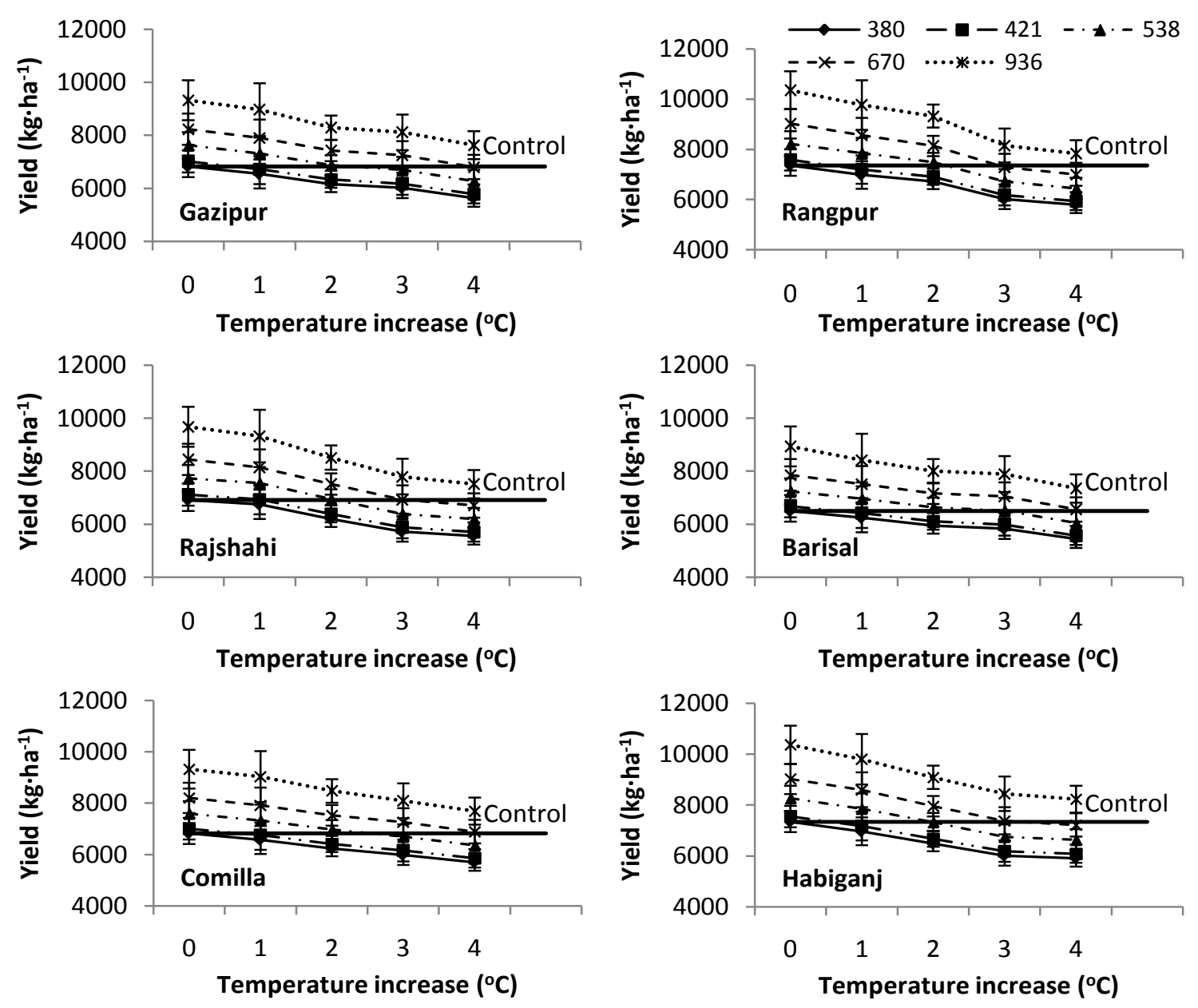

Figure 3. Estimated rice yield of BRRI dhan28 under varied temperature and $\mathrm{CO}_{2}$ levels in different regions of Bangladesh; Error bars indicate the standard deviation.

was minimum $(0.4 \%-3 \%)$ because of temperature rise up to $2^{\circ} \mathrm{C}$. This part of the country generally enjoys cooler environment for a longer period in winter season and thus predicted temperature increase by $2^{\circ} \mathrm{C}$ might not be hazardous for Boro rice production in future.

Grain yield reduction as predicted through the use of ORYZA1 and INFOCROP rice models with $1^{\circ} \mathrm{C}$ increase in temperature was $7.20 \%$ and $6.66 \%$, respectively at $380 \mathrm{ppm} \mathrm{CO}$ level [47]. Increased $\mathrm{CO}_{2}$ concentration up to 700 ppm, however, showed $30.73 \%$ and $56.37 \%$ higher yield by ORYZA1 and INFOCROP crop model, respectively. When temperature was increased by about $4^{\circ} \mathrm{C}$ above the ambient level, ORYZA1 predicted yield reductions of 7.63\%, 9.38\% and 15.86\%, respectively based on General Fluid Dynamics Laboratory (GFDL) Model, Goddard Institute of Space Studies (GISS) model and the United Kingdom Meteorological Office (UKMO) model; while INFOCROP predicted reductions of $9.02 \%, 11.30 \%$ and $21.35 \%$. We have found less yield reduction than their findings. Moreover, IPCC [14] and BBS [48] estimated 8\% - 17\% decline in rice production by 2050 in South Asian region which is similar to our findings. 

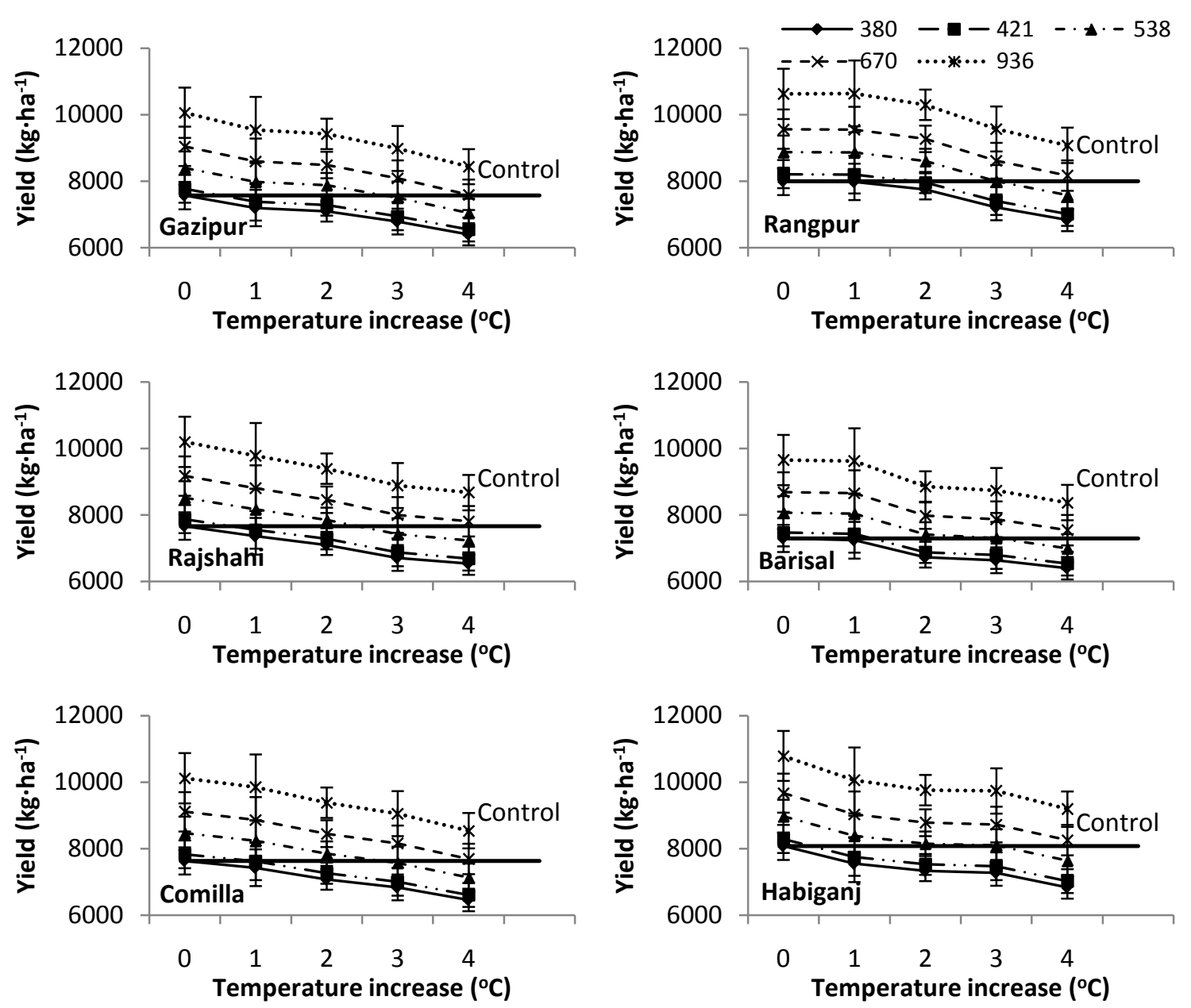

Figure 4. Estimated rice yield of BRRI dhan29 under varied temperature and $\mathrm{CO}_{2}$ levels in different regions of Bangladesh; Error bars indicate the standard deviation.

An increase in air $\mathrm{CO}_{2}$ level generally increased crop yield because of stimulated photosynthetic processes and improved water use efficiency [49]. In general, the effect of increased temperature would be negative because of increasing respiration [50] and a shortened vegetative and grain filling period [46]. Although major rice models indicate about $5 \%$ yield reduction for every degree rise in mean temperature [51] and Dias et al. [52] estimated 25\% - 35\% yield reduction in Sri Lanka using DSSAT. Basak et al. [31] reported 20\% and 50\% yield reduction by 2050 and 2070, respectively in Boro season with BR3 and BR14 rice varieties. These greater predicted yield reductions could be because of response behavior of studied varieties or use of inappropriate genetic coefficients in the model.

All the study regions had lower minimum average temperature at sowing (middle of November) and transplanting (January) time and it increased during tillering, panicle initiation and flowering stages. After nineties, cold spell at Rangpur and Rajshahi areas was is increasing trend that might have inflicted cold injury of Boro rice seedlings (Table 4). In Gazipur, Rajshahi and Habiganj 

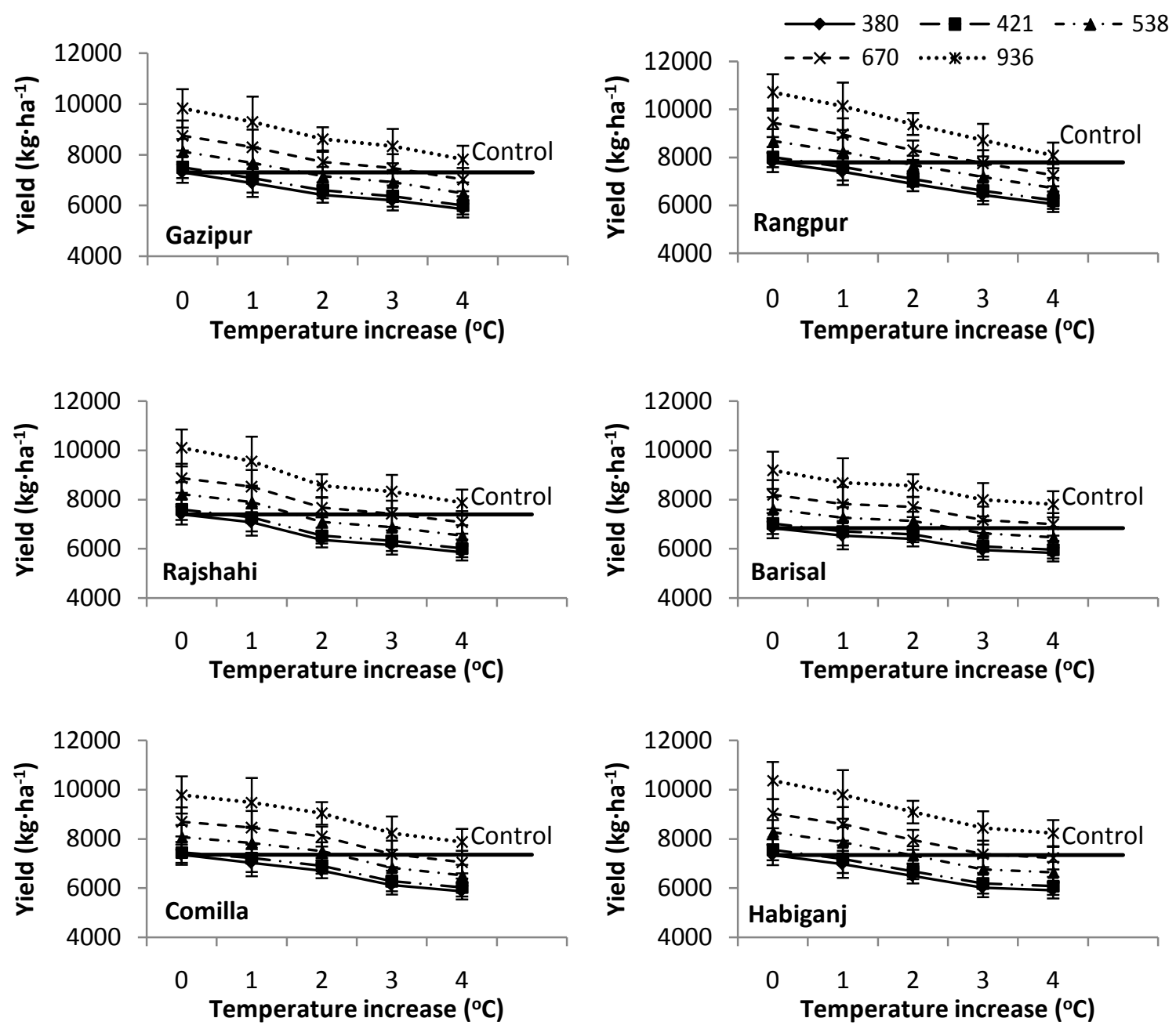

Figure 5. Estimated rice yield of BRRI dhan58 under varied temperature and $\mathrm{CO}_{2}$ levels in different regions of Bangladesh; Error bars indicate the standard deviation.

regions, warm spells were in increasing trend resulting in reduced rice production in those areas (Table 4). At flowering stage, maximum temperature was about $33.3^{\circ} \mathrm{C}-36.1^{\circ} \mathrm{C}$ in Rajshahi, $31.9^{\circ} \mathrm{C}-33.6^{\circ} \mathrm{C}$ in Gazipur, $30.4^{\circ} \mathrm{C}-31.7^{\circ} \mathrm{C}$ in Rangpur, $32.4^{\circ} \mathrm{C}-33.6^{\circ} \mathrm{C}$ in Barisal, $30.9^{\circ} \mathrm{C}-32.5^{\circ} \mathrm{C}$ in Comilla and $31.7^{\circ} \mathrm{C}$ $32.9^{\circ} \mathrm{C}$ in Habiganj regions and sometimes it goes beyond the critical level $\left(>35^{\circ} \mathrm{C}\right)$. High temperature generally prevails in March through May (Figure 2) and thus spikelet sterility and increased respiratory loss are most likely depending on growth stages of rice crops. Rice pollen viability and its production decline as daytime maximum temperature exceeds $33^{\circ} \mathrm{C}$ and ceases beyond $40^{\circ} \mathrm{C}$ [53]. In grain filling stage, kernel weight of rice decreases greatly below and above $24^{\circ} \mathrm{C}$ temperature [54]. In the projected climate change scenarios, the maximum temperature at flowering stage of rice will be beyond the critical limit and thus reduction of rice yield is a must. To avoid this situation, shifting the sowing window of Boro rice and to develop cold and heat tolerant rice varieties may be the option for sustaining food security in Bangladesh. 


\subsection{Effects of $\mathrm{CO}_{2}$ and Temperature on Growth Duration}

In all studied regions, growth duration of rice varieties was not significantly influenced by $\mathrm{CO}_{2}$ levels but it was reduced by $7.45,7.49$ and 7.88 days for BRRI dhan 28, BRRI dhan 29 and BRRI dhan58, respectively with every degree increase in temperature compared to ambient temperature (Figure 6 and Table 5). Mahmood [24] also reported 7 - 8 days reduced growth duration of BR3 per $1^{\circ} \mathrm{C}$ rise in temperature. Biswas et al. [55] reported that both growth duration and grain yield of rice reduces depending on planting time. The lowest growth duration reduction was predicted for Barisal and Rajshahi regions for all temperature levels (Table 5). Since growth duration influences grain yield in most cases, reduced life span might be the cause of reduced yield in future.

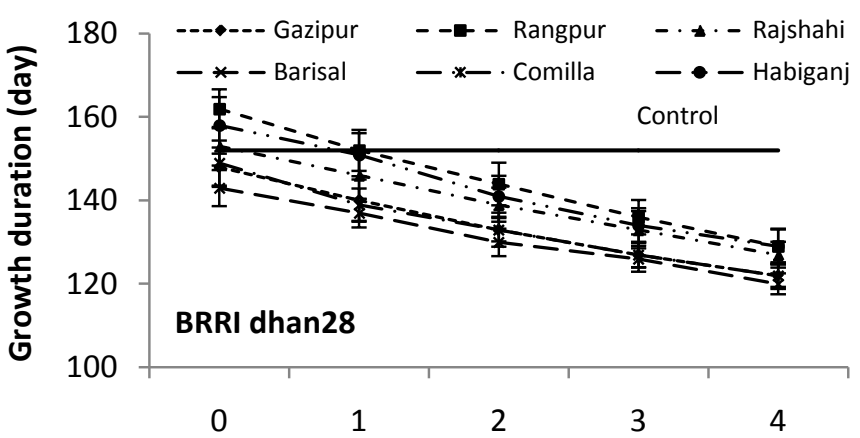

Temperature increase $\left({ }^{\circ} \mathrm{C}\right)$
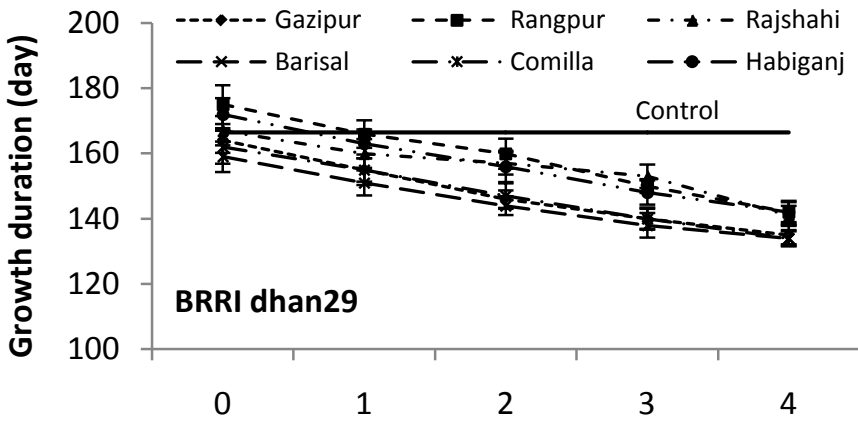

Temperature increase $\left({ }^{\circ} \mathrm{C}\right)$

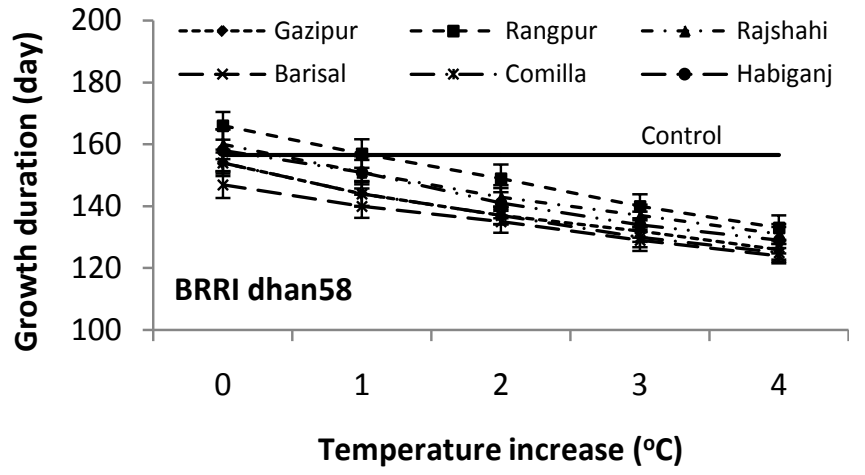

Figure 6. Growth durations of BRRI dhan28, BRRI dhan29 and BRRI dhan 58 as affected by temperature under different regions of Bangladesh; Error bars indicate the standard deviation. 
Table 5. Growth duration reductions (days) with different varieties at varied regions of Bangladesh.

\begin{tabular}{ccccccccccccc}
\hline & \multicolumn{3}{c}{ BRRI dhan28 } & \multicolumn{3}{c}{ BRRI dhan29 } & \multicolumn{3}{c}{ BRRI dhan58 } \\
\cline { 2 - 11 } Locations & \multicolumn{1}{c}{ Increase in temperature } \\
\cline { 2 - 12 } & $+\mathbf{+ 1}$ & $\mathbf{+ 2}$ & $\mathbf{+ 3}$ & $\mathbf{+ 4}$ & $\mathbf{+ 1}$ & $\mathbf{+ 2}$ & $\mathbf{+ 3}$ & $\mathbf{+ 4}$ & $\mathbf{+ 1}$ & $\mathbf{+ 2}$ & $\mathbf{+ 3}$ & $\mathbf{+ 4}$ \\
\hline Gazipur & 8 & 15 & 21 & 26 & 9 & 18 & 24 & 29 & 10 & 17 & 22 & 28 \\
Rangpur & 10 & 18 & 26 & 33 & 9 & 15 & 25 & 33 & 9 & 17 & 26 & 33 \\
Rajshahi & 7 & 14 & 20 & 26 & 7 & 10 & 14 & 26 & 9 & 17 & 23 & 29 \\
Barisal & 6 & 13 & 17 & 23 & 8 & 15 & 21 & 25 & 7 & 12 & 18 & 23 \\
Comilla & 10 & 16 & 22 & 27 & 7 & 15 & 22 & 28 & 10 & 17 & 24 & 29 \\
Habiganj & 7 & 17 & 24 & 29 & 9 & 16 & 24 & 30 & 7 & 17 & 24 & 29 \\
\hline
\end{tabular}

\subsection{Combined Effects of Temperature and $\mathrm{CO}_{2}$ on Yield}

At the ambient $\mathrm{CO}_{2}$ concentration, grain yield of rice is likely to be reduced by $16.4 \%-21.3 \%$ for BRRI dhan28 (Table 6), $12.2 \%-15.4 \%$ for BRRI dhan 29 (Table 7) and $14.8 \%-22.3 \%$ for BRRI dhan58 (Table 8) if temperature increases by $4^{\circ} \mathrm{C}$. But $936 \mathrm{ppm} \mathrm{CO}_{2}$ concentration (RCPs 8.5 ) might increase yield by $36.6 \%-41.1 \%$ for BRRI dhan28 (Table 6), 32.3\% - 33.6\% for BRRI dhan 29 (Table 7) and $33.1 \%-41.1 \%$ for BRRI dhan58 (Table 8) in different regions of Bangladesh with existing temperature pattern. In most areas, BRRI dhan28 showed a competitive yield advantage under ambient conditions (no temperature rise and $380 \mathrm{ppm} \mathrm{CO}_{2}$ ) that extended up to $2^{\circ} \mathrm{C}$ temperature rise with 538 ppm $\mathrm{CO}_{2}$ level except in southern Bangladesh. Grain yield reduction due to $3^{\circ} \mathrm{C}$ temperature rise could be compensated up to $670 \mathrm{ppm} \mathrm{CO}_{2}$ level in all studied regions except in Rangpur areas. Similarly, if $\mathrm{CO}_{2} 936 \mathrm{ppm}$ level might be able to compensate grain yield reduction due to $4^{\circ} \mathrm{C}$ rise in all test regions of Bangladesh (Table 6). BRRI dhan29 showed similar trends and are more tolerant to adverse conditions than BRRI dhan28. In Rangpur and Habiganj regions, grain yield reductions due to $3^{\circ} \mathrm{C}$ rise were compensated with $538 \mathrm{ppm} \mathrm{CO}$ level; but in Gazipur, Rajshahi and Comilla regions, yield compensation is likely for $2^{\circ} \mathrm{C}$ under same $\mathrm{CO}_{2}$ level. Grain yield reductions because of temperature rise up to $4^{\circ} \mathrm{C}$ are likely to be compensated by the presence of $670 \mathrm{ppm} \mathrm{CO}_{2}$ for all the studied regions for BRRI dhan29 (Table 7). BRRI dhan58 showed more vulnerable in response to elevated temperature. In most of the regions, yield compensation is likely for $1^{\circ} \mathrm{C}$ temperature rise with $538 \mathrm{ppm} \mathrm{CO}_{2}$ except Barisal and Comilla regions. Yield compensation could be extended for $3^{\circ} \mathrm{C}$ temperature rise by 670 ppm $\mathrm{CO}_{2}$ level except in Rangpur areas and $936 \mathrm{ppm} \mathrm{CO}_{2}$ for $4^{\circ} \mathrm{C}$ temperature rise in all test regions (Table 8). Baker et al. [49] and Figueiredo et al. [56] also reported that yield reduction due to higher temperature can be compensated with increased $\mathrm{CO}_{2}$ level. Horie et al. [57] reported that $100 \mu \mathrm{mol} \cdot \mathrm{mol}^{-1}$ increased in $\mathrm{CO}_{2}$ concentration gave $7 \%-8 \%$ greater rice yield in Japan, but $2^{\circ} \mathrm{C}$ rise in temperature significantly reduced such beneficial effect. 
Table 6. Percent changes in grain yield as affected by increased temperature and elevated $\mathrm{CO}_{2}$ concentration over control (no temperature rise, $380 \mathrm{ppm} \mathrm{CO}_{2}$ ) for BRRI dhan28 at various test regions of Bangladesh.

\begin{tabular}{|c|c|c|c|c|c|c|c|c|c|c|}
\hline \multirow{3}{*}{$\begin{array}{c}\mathrm{CO}_{2} \text { level } \\
(\mathrm{ppm})\end{array}$} & \multicolumn{10}{|c|}{ Temperature rise $\left({ }^{\circ} \mathrm{C}\right)$} \\
\hline & \multicolumn{5}{|c|}{ Gazipur } & \multicolumn{5}{|c|}{ Rangpur } \\
\hline & 0 & +1 & +2 & +3 & +4 & 0 & +1 & +2 & +3 & +4 \\
\hline 380 & 0.0 & -4.2 & -9.7 & -11.9 & -17.5 & 0.0 & -5.1 & -8.7 & -18.3 & -21.3 \\
\hline 421 & 2.8 & -1.5 & -7.2 & -9.6 & -15.2 & 2.9 & -2.3 & -6.1 & -16.0 & -19.3 \\
\hline 538 & 11.7 & 7.1 & 0.8 & -1.8 & -8.1 & 11.7 & 6.6 & 1.8 & -8.7 & -12.5 \\
\hline 670 & 20.6 & 15.7 & 8.7 & 6.1 & -0.4 & 22.6 & 16.3 & 10.5 & -1.0 & -4.9 \\
\hline \multirow[t]{2}{*}{936} & 36.6 & 31.3 & 21.4 & 18.8 & 11.7 & 40.6 & 32.6 & 26.6 & 10.8 & 6.5 \\
\hline & \multicolumn{5}{|c|}{ Rajshahi } & \multicolumn{5}{|c|}{ Barisal } \\
\hline 380 & 0.0 & -2.4 & -10.3 & -17.2 & -19.6 & 0.0 & -4.0 & -8.5 & -10.3 & -16.4 \\
\hline 421 & 2.9 & 0.3 & -7.6 & -14.9 & -17.4 & 2.7 & -1.3 & -6.0 & -7.9 & -14.3 \\
\hline 538 & 11.8 & 9.2 & 0.5 & -7.6 & -10.4 & 11.3 & 7.2 & 2.1 & 0.1 & -7.0 \\
\hline 670 & 22.0 & 17.7 & 8.6 & 0.2 & -2.9 & 20.9 & 15.6 & 10.2 & 8.4 & 0.9 \\
\hline \multirow[t]{2}{*}{936} & 40.0 & 34.8 & 23.1 & 12.8 & 8.6 & 37.3 & 29.5 & 23.0 & 21.4 & 13.0 \\
\hline & \multicolumn{5}{|c|}{ Comilla } & \multicolumn{5}{|c|}{ Habiganj } \\
\hline 380 & 0.0 & -3.6 & -8.5 & -12.3 & -16.4 & 0.0 & -5.2 & -11.7 & -18.1 & -19.5 \\
\hline 421 & 2.8 & -0.9 & -6.0 & -9.8 & -14.2 & 2.8 & -2.3 & -9.1 & -15.7 & -17.1 \\
\hline 538 & 11.3 & 7.5 & 2.3 & -1.8 & -6.7 & 12.5 & 6.9 & -0.2 & -8.0 & -9.7 \\
\hline 670 & 20.4 & 16.2 & 10.4 & 6.5 & 1.1 & 22.8 & 17.1 & 8.3 & 0.5 & -1.7 \\
\hline 936 & 36.7 & 32.5 & 24.3 & 18.6 & 12.8 & 41.1 & 33.4 & 23.7 & 15.0 & 12.1 \\
\hline
\end{tabular}

Table 7. Percent changes in grain yield as affected by increased temperature and elevated $\mathrm{CO}_{2}$ concentration over control (no temperature rise, $380 \mathrm{ppm} \mathrm{CO}_{2}$ ) for BRRI dhan29 at various test regions of Bangladesh.

\begin{tabular}{|c|c|c|c|c|c|c|c|c|c|c|}
\hline \multirow{3}{*}{$\mathrm{CO}_{2}$ level (ppm) } & \multicolumn{10}{|c|}{ Temperature increase level } \\
\hline & \multicolumn{5}{|c|}{ Gazipur } & \multicolumn{5}{|c|}{ Rangpur } \\
\hline & 0 & +1 & +2 & +3 & +4 & 0 & +1 & +2 & +3 & +4 \\
\hline 380 & 0.0 & -5.0 & -6.3 & -10.3 & -15.4 & 0.0 & -0.2 & -3.0 & -9.8 & -14.6 \\
\hline 421 & 2.7 & -2.4 & -3.8 & -8.2 & -13.5 & 2.7 & 2.5 & -0.4 & -7.4 & -12.3 \\
\hline 538 & 11.0 & 5.5 & 4.1 & -0.8 & -6.9 & 11.0 & 10.9 & 7.7 & 0.1 & -5.2 \\
\hline 670 & 19.5 & 13.6 & 12.1 & 6.9 & 0.3 & 19.6 & 19.5 & 16.0 & 7.8 & 2.1 \\
\hline \multirow[t]{2}{*}{936} & 32.9 & 26.1 & 24.5 & 18.7 & 11.5 & 32.9 & 33.0 & 28.8 & 19.7 & 13.5 \\
\hline & \multicolumn{5}{|c|}{ Rajshahi } & \multicolumn{5}{|c|}{ Barisal } \\
\hline 380 & 0.0 & -4.0 & -7.4 & -12.5 & -14.7 & 0.0 & -0.7 & -7.8 & -9.0 & -12.2 \\
\hline 421 & 2.7 & -1.4 & -5.0 & -10.3 & -12.8 & 2.5 & 1.9 & -5.7 & -6.9 & -10.4 \\
\hline 538 & 11.1 & 6.6 & 2.5 & -3.2 & -5.6 & 10.7 & 10.2 & 1.6 & 0.1 & -4.0 \\
\hline 670 & 19.6 & 14.8 & 10.3 & 4.3 & 1.9 & 19.1 & 18.7 & 9.4 & 7.9 & 3.4 \\
\hline \multirow[t]{2}{*}{936} & 33.0 & 27.5 & 22.6 & 15.9 & 13.1 & 32.3 & 31.8 & 21.4 & 19.8 & 14.8 \\
\hline & \multicolumn{5}{|c|}{ Comilla } & \multicolumn{5}{|c|}{ Habiganj } \\
\hline 380 & 0.0 & -2.7 & -7.3 & -10.4 & -15.4 & 0.0 & -6.5 & -9.2 & -9.9 & -15.4 \\
\hline 421 & 2.6 & -0.2 & -4.9 & -8.2 & -13.4 & 2.7 & -4.0 & -6.8 & -7.5 & -13.0 \\
\hline 538 & 10.9 & 7.9 & 2.8 & -0.8 & -6.6 & 11.1 & 3.9 & 0.9 & 0.3 & -5.4 \\
\hline 670 & 19.4 & 16.2 & 10.7 & 6.9 & 0.7 & 19.7 & 11.9 & 8.7 & 8.1 & 2.3 \\
\hline 936 & 32.5 & 29.0 & 22.9 & 18.6 & 11.9 & 33.6 & 24.5 & 20.8 & 20.6 & 13.8 \\
\hline
\end{tabular}


Table 8. Percent changes in grain yield as affected by increased temperature and elevated $\mathrm{CO}_{2}$ concentrations over control (no temperature rise, $380 \mathrm{ppm} \mathrm{CO}_{2}$ ) for BRRI dhan58 at various test regions of Bangladesh.

\begin{tabular}{|c|c|c|c|c|c|c|c|c|c|c|}
\hline \multirow{3}{*}{$\begin{array}{c}\mathrm{CO}_{2} \text { level } \\
\text { (ppm) }\end{array}$} & \multicolumn{10}{|c|}{ Temperature increase level } \\
\hline & \multicolumn{5}{|c|}{ Gazipur } & \multicolumn{5}{|c|}{ Rangpur } \\
\hline & 0 & +1 & +2 & +3 & +4 & 0 & +1 & +2 & +3 & +4 \\
\hline 380 & 0.0 & -5.7 & -12.0 & -15.1 & -19.7 & 0.0 & -5.0 & -11.5 & -17.5 & -22.3 \\
\hline 421 & 2.7 & -3.0 & -9.7 & -12.8 & -17.7 & 2.7 & -2.5 & -9.0 & -15.2 & -20.2 \\
\hline 538 & 11.2 & 5.1 & -2.0 & -5.2 & -11.1 & 11.3 & 5.6 & -1.3 & -7.9 & -13.8 \\
\hline 670 & 19.9 & 13.7 & 5.7 & 2.5 & -3.8 & 21.0 & 14.7 & 6.5 & -0.4 & -6.9 \\
\hline \multirow[t]{2}{*}{936} & 34.5 & 27.3 & 18.1 & 14.2 & 7.2 & 37.3 & 29.9 & 20.4 & 11.8 & 3.7 \\
\hline & \multicolumn{5}{|c|}{ Rajshahi } & \multicolumn{5}{|c|}{ Barisal } \\
\hline 380 & 0.0 & -4.2 & -14.0 & -16.8 & -20.7 & 0.0 & -4.5 & -6.3 & -13.1 & -14.8 \\
\hline 421 & 2.7 & -1.6 & -11.6 & -14.4 & -18.6 & 2.7 & -1.9 & -3.7 & -10.8 & -12.8 \\
\hline 538 & 11.1 & 6.8 & -4.1 & -7.0 & -11.6 & 11.2 & 6.2 & 4.3 & -3.0 & -5.5 \\
\hline 670 & 19.9 & 15.3 & 3.8 & 0.4 & -4.3 & 19.8 & 14.4 & 12.5 & 4.9 & 2.3 \\
\hline \multirow[t]{2}{*}{936} & 36.6 & 29.3 & 15.9 & 12.6 & 6.5 & 34.3 & 27.0 & 25.3 & 16.9 & 14.1 \\
\hline & \multicolumn{5}{|c|}{ Comilla } & \multicolumn{5}{|c|}{ Habiganj } \\
\hline 380 & 0.0 & -4.4 & -8.8 & -16.8 & -20.1 & 0.0 & -5.2 & -11.7 & -18.1 & -19.5 \\
\hline 421 & 1.3 & -1.7 & -6.2 & -14.5 & -18.1 & 2.8 & -2.3 & -9.1 & -15.7 & -17.1 \\
\hline 538 & 9.7 & 6.6 & 1.9 & -7.1 & -11.3 & 12.5 & 6.9 & -0.2 & -8.0 & -9.7 \\
\hline 670 & 18.2 & 14.9 & 10.0 & 0.4 & -4.1 & 22.8 & 17.1 & 8.3 & 0.5 & -1.7 \\
\hline 936 & 33.1 & 28.9 & 22.9 & 12.0 & 7.0 & 41.1 & 33.4 & 23.7 & 15.0 & 12.1 \\
\hline
\end{tabular}

\section{Conclusion}

This study was conducted to determine the effect of increased daily maximum and minimum temperatures and elevated $\mathrm{CO}_{2}$ levels using CERES-Rice model on grain yield and growth duration of dry season rice (Boro) at six representative locations across Bangladesh. Long-term normalized weather data were used to predict grain yields of those varieties under variable increased temperature and $\mathrm{CO}_{2}$ levels. Temperature increase rate considered was $0,+1^{\circ} \mathrm{C},+2^{\circ} \mathrm{C},+3^{\circ} \mathrm{C}$ and $+4^{\circ} \mathrm{C}$ with the elevated $\mathrm{CO}_{2}$ concentrations of 380,421,538,670 and 936 ppm based on different RCPs. Rice grain yield was reduced by $256-403 \mathrm{~kg} \cdot \mathrm{ha}^{-1}$ for BRRI dhan28, 172 - $370 \mathrm{~kg} \cdot \mathrm{ha}^{-1}$ for BRRI dhan29 and $268-432 \mathrm{~kg} \cdot \mathrm{ha}^{-1}$ for BRRI dhan 58 per $1^{\circ} \mathrm{C}$ temperature rise. On the contrary, $\mathrm{CO}_{2}$ concentration compensated yield by $225-275 \mathrm{~kg} \cdot \mathrm{ha}^{-1}$ for BRRI dhan $28,230-267 \mathrm{~kg} \cdot \mathrm{ha}^{-1}$ for

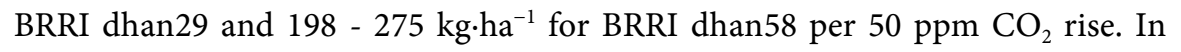
general, grain yield reduction and compensation rate were lower in warmer region and higher in cooler region. Growth duration was reduced by about 9 days irrespective of locations and varieties with an exception for BRRI dhan58, which has comparatively less growth duration reduction per degree temperature rise. In the projected climate change scenarios, maximum temperature at flowering stage of rice might cross the critical limit and thus reduction in rice yield is ex- 
pected. To avoid this situation, shifting of sowing window for Boro rice and to develop cold and heat tolerant rice varieties would be the options for sustaining food security in Bangladesh and similar environments in other parts of the world.

\section{Acknowledgements}

The authors acknowledge the Modeling Climate Change on Agriculture Project (CRP-II, KGF) for funding this study. This finding is the outcome of the collaborative research of BRRI, BARI and BSMRAU.

\section{References}

[1] UN (United Nations) (2015) United Nations Department of Economic and Social Affairs. World Population Prospects, the 2015 Revision. http://esa.un.org/wpp/unpp/ panel_population.htm

[2] Hasan, M.N., Hossain, M.S., Bari, M.A. and Islam, M.R. (2013) Agricultural Land Availability in Bangladesh. SRDI, Dhaka, 42.

[3] MoEF (Ministry of Environment and Forest) (2005) National Adaptation Program of Action (NAPA). Government of Bangladesh, Dhaka.

[4] DoE (Department of Environment) (2007) Climate Change and Bangladesh. Ministry of Environment and Forest, Government of Bangladesh, Dhaka.

[5] Huq, S. and Rabbani, G. (2011) Climate Change and Bangladesh: Policy and Institutional Development to Reduce Vulnerability. Journal of Bangladesh Studies, 13, $1-10$.

[6] Hossain, A. and Silva, J.A.T. (2013) Wheat Production in Bangladesh: Its Future in the Light of Global Warming. AoB Plants, 5, pls042.

https://doi.org/10.1093/aobpla/pls042

[7] MoA-FAO (2012) Master Plan for Agricultural Development in the Southern Region of Bangladesh. Ministry of Agriculture (MoA, Government of Bangladesh) and United Nations Food and Agriculture Organization, Dhaka, 122.

[8] IPCC (2013) Summary for Policymakers. In: Stocker, T.F., Qin, D., Plattner, G.K., Tignor, M., Allen, S.K., Boschung, J., Nauels, A., Xia, Y., Bex, V. and Midgley, P.M., Eds., Climate Change 2013: The Physical Science Basis. Contribution of Working Group I to the Fifth Assessment Report of the Intergovernmental Panel on Climate Change, Cambridge University Press, Cambridge, United Kingdom and New York.

[9] IPCC (1996) Climate Change 1995: The Science of Climate Change. In: Houghton, J.T., Meira Filho, L.G., Callander, B.A., Harris, N., Kattenberg, A. and Maskell, K., Eds., Climate Change 1995: The Science of Climate Change, Cambridge University Press, Cambridge, 572.

[10] Fan, Y., Liang, Q.M., Wei, Y.M. and Okada, N. (2007) A Model for China's Energy Requirements and $\mathrm{CO}_{2}$ Emissions Analysis. Environmental Modelling \& Software, 22, 378-393. https://doi.org/10.1016/j.envsoft.2005.12.007

[11] UNDP (United Nations Development Program) (2008) Fighting Climate Change: Human Solidarity in a Divided World. Human Development Report. Oxford University Press, Oxford.

[12] GOB (Government of Bangladesh) \& UNDP (United Nations Development Program) (2009) The Probable Impacts of Climate Change on Poverty and Economic Growth and Options of Coping with Adverse Effects of Climate Change in Bangla- 
desh. Policy Study, Dhaka.

[13] BBS (Bangladesh Bureau of Statistics) (2015) Yearbook of Agricultural Statistics of Bangladesh. Government of Bangladesh, Dhaka.

[14] IPCC (Intergovernmental Panel on Climate Change) (2007) Climate Change 2007: Impacts, Adaptation and Vulnerability: Contribution of Working Group II to the Fourth Assessment Report of the Intergovernmental Panel on Climate Change. Cambridge University Press, Cambridge.

[15] BBS (Bangladesh Bureau of Statistics) (2016) Yearbook of Agricultural Statistics of Bangladesh. Government of Bangladesh, Dhaka.

[16] Asaduzzaman, M., Ringler, C., Thurlow, J. and Alam, S. (2010) Investing in Crop Agriculture in Bangladesh for Higher Growth and Productivity, and Adaptation to Climate Change. Bangladesh Food Security Investment Forum, Dhaka.

[17] Gbetibouo, G.A. and Hassan, R.M. (2005) Measuring the Economic Impact of Climate Change on Major South African Crops: A Ricardian Approach. Global and Planetary Change, 47, 143-152. https://doi.org/10.1016/j.gloplacha.2004.10.009

[18] Kurukulasuriya, P. and Ajwad, M.I. (2007) Application of the Ricardian Technique to Estimate the Impact of Climate Change on Smallholder Farming in Sri Lanka. Climatic Change, 81, 39-59. https://doi.org/10.1007/s10584-005-9021-2

[19] Haim, D., Shechter, M. and Berliner, P. (2008) Assessing the Impact of Climate Change on Representative Field Crops in Israel Agriculture: A Case Study of Wheat and Cotton. Climatic Change, 86, 425-440. https://doi.org/10.1007/s10584-007-9304-x

[20] Sanghi, A. and Mendelsohn, R. (2008) The Impact of Global Warming on Farmers in Brazil and India. Global Environmental Change, 18, 655-665. https://doi.org/10.1016/j.gloenvcha.2008.06.008

[21] Deressa, T.T. and Hassan, R.M. (2009) Economic Impact of Climate Change on Crop Production in Ethiopia: Evidence from Cross-Section Measures. Journal of African Economies, 18, 529-554. https://doi.org/10.1093/jae/ejp002

[22] Moula, E.L. (2009) An Empirical Assessment of the Impact of Climate Change on Smallholder Agriculture in Cameroon. Global and Planetary Change, 67, 205-208. https://doi.org/10.1016/j.gloplacha.2009.02.006

[23] Wang, J., Mendelsohn, R., Dinar, A., Huang, J., Rozelle, S. and Zhang, L. (2009) The Impact of Climate Change on China's Agriculture. Agricultural Economics, 40, 323-337. https://doi.org/10.1111/j.1574-0862.2009.00379.x

[24] Mahmood, R. (1998) Air Temperature Variations and Rice Productivity in Bangladesh: A Comparative Study of the Performance of the YIELD and CERES-Rice Models. Ecological Modelling, 106, 201-212. https://doi.org/10.1016/S0304-3800(97)00192-0

[25] Paul, B.K. (1998) Coping Mechanism Practiced by Drought Victims (1994/5) in North Bengal, Bangladesh. Applied Geography, 18, 355-373. https://doi.org/10.1016/S0143-6228(98)00026-5

[26] Ali, A. (1999) Climate Change Impacts and Adaptation Assessment in Bangladesh. Climate Research, 12, 109-116. https://doi.org/10.3354/cr012109

[27] Rahman, M.S. (2000) A Rainfall Simulation Model for Agricultural Development in Bangladesh. Discrete Dynamics in Nature and Society, 5, 1-7. https://doi.org/10.1155/S1026022600000339

[28] Rashid, M.H. and Islam, M.S. (2007) Adaptation to Climate Change for Sustainable Development of Bangladesh Agriculture. Bangladesh Country Paper. 
[29] Karim, Z., Hussain, S. and Ahmed, M. (1996) Assessing Impacts of Climate Variations on Food Grain Production in Bangladesh. Water, Air, \& Soil Pollution, 92, 53-62.

[30] Mahmood, R., Legates, D.R. and Meo, M. (2004) The Role of Soil Water Availability in Potential Rainfed Rice Productivity in Bangladesh: Applications of the CERES-Rice Model. Applied Geography, 24, 139-159. https://doi.org/10.1016/j.apgeog.2004.03.001

[31] Basak, J.K., Ali, M.A., Islam, M.N. and Rashid, M.A. (2010) Assessment of the Effect of Climate Change on Boro Rice Production in Bangladesh Using DSSAT Model. Civil Engineering Journal, 38, 95-108.

[32] Ritchie, J.T., Alocilja, E.C., Singh, U. and Uehara, G. (1987) IBSNAT and the CERES-Rice Model. Proceedings of the International Workshop on the Impact of Weather Parameters on Growth and Yield of Rice, Manilla, 7-10 April 1986, 271-281.

[33] Tsuji, G.Y., Uehara, G and Balas, G. (1994) DSSAT Version 3, Vols. 1-3. University of Hawaii, Hawaii.

[34] Zhang, X. and Yang, F. (2004) RClimDex 1.0 User Manual. Climate Research Branch, Environment Canada, Downsview.

[35] Ritchie, J.T. (1991) Wheat Phasic Development. In: Hanks, J. and Ritchie, J.T., Eds., Modelling Plant and Soil System, Agron. Mongr., ASA, CSSA, Medison, 31.

[36] Kropff, M.J., van Laar, H.H. and Matthews, R.B. (1994) ORYZA1: An Eco-Physical Model for Irrigated Rice Production. In: SARP Research Proceedings, IRRI, Los Banos, Philippines, and AB-DLO, Wageningen, $110 \mathrm{p}$.

[37] Kropff, M.J., Teng, P.S., Aggarwal, P.K., Bouman, B.A.M. and van Laar, H.H. (1997) Application of Systems Approaches at the Field Level. Vol. 2, Kluwer Academic Publishers, Dordrecht, 465 p. https://doi.org/10.1007/978-94-017-0754-1

[38] Aggarwal, P.K., Kropff, M.J., Cassman, K.G. and ten Berge, H.F.M. (1997) Simulating Genetic Strategies for Increased Yield Potential in Irrigated, Tropical Environments. Field Crops Research, 51, 5-18. https://doi.org/10.1016/S0378-4290(96)01044-1

[39] Aggarwal, P.K., Talukder, K.K. and Mall, R.K. (2000) Potential Yields of the Rice-Wheat System in the Indo-Gangetic Plains in India. Rice-Wheat Consortium Paper Series 10. Rice-Wheat Consortium for the Indo-Gangetic Plains, New Delhi, India and Indian Agricultural Research Institute, New Delhi, 11 p.

[40] Mall, R.K. and Aggarwal, P.K. (2002) Climate Change and Rice Yields in Diverse Agro-Environments in India. I. Evaluation of Impact Assessment Models. Climate Change, 52, 315-330. https://doi.org/10.1023/A:1013702105870

[41] Jones, J.W., Hunt, L.A., Hoogenboom, G., Godwin, D.C., Singh, U., Tsuji, G.Y., Pickering, N.B., Thomton, P.K., Bowen, W.T., Boote, K.J. and Ritchie, J.T. (1994) Crop Models. In: Tsuji, G.Y., Uehera, G. and Balas, S., Eds., DSSAT Version 3, Vol. 2, University of Hawaii, Honolulu, 284 p.

[42] Maniruzzaman, M., Biswas, J.C., Hossain, M.B., Haque, M.M., Naher, U.A., Biswas, A., Choudhury, A.K., Akhter, S., Ahmed, F., Rahman, M.M. and Kalra, N. (2017) Evaluating the CERES-Rice Model under Dry Season Irrigated Rice in Bangladesh: Calibration and Validation. Journal of Agricultural and Crop Research, 5, 96-107.

[43] Pathak, H., Ladha, J.K., Aggarwal, P.K., Peng, S., Das, S., Singh, Y., Singh, B., Kamra, S.K., Mishra, B., Sastri, A.P.R.A.S., Aggarwal, H.P., Das, D.K. and Gupta, R.K. (2003) Trends of Climate Potential and On-Farm Yields of Rice and Wheat in the 
Indo-Gangetic Plains. Field Crops Research, 80, 223-234. https://doi.org/10.1016/S0378-4290(02)00194-6

[44] Mohandas, S., Kareem, A.K., Ranganathan, T.B. and Jeyaraman, S. (1995) Rice Production in India under Current and Future Climates. In: Matthews, R.B., Kropff, M.J., Bachelet, D. and van Laar, H.H., Eds., Modeling the Impact of Climate Change on Rice Production in Asia, Cab International and International Rice Research Institute, Los Banos, 165-181.

[45] Krishnan, P., Ramakrishnan, B., Raja Reddy, K. and Reddy, V.R. (2011) High Temperature Effects on Rice Growth, Yield, and Grain Quality. In: Sparks, D.L., Ed., Advances in Agronomy, Vol. 111, Academic Press, Burlington, 87-206.

[46] Horie, T., Nakagawa, H., Ceneno, H.G.S. and Kropff, M.J. (1995) The Rice Crop Simulation Model SIMRIW and Its Testing. In: Matthews, R.B., Kropff, M.J., Bachelet, D. and van Laar, H.H., Eds., Modeling the Impact of Climate Change on Rice Production in Asia, Cab International and International Rice Research Institute, Los Banos, 51-66.

[47] Krishnan, P., Swain, D.K., Bhaskar B.C., Nayak, S.K. and Dash, R.N. (2007) Impact of Elevated $\mathrm{CO}_{2}$ and Temperature on Rice Yield and Methods of Adaptation as Evaluated by Crop Simulation Studies. Agriculture, Ecosystems and Environment, 122, 233-242. https://doi.org/10.1016/j.agee.2007.01.019

[48] BBS (Bangladesh Bureau of Statistics) (2005) Yearbook of Agricultural Statistics of Bangladesh. Government of Bangladesh, Dhaka.

[49] Baker, J.T., Allen, L.H. and Boote, K.J. (1990) Growth and Yield Responses of Rice to Carbon Dioxide Concentration. The Journal of Agricultural Science, 115, 313-320.

[50] Penning de Vries, F.W.T. (1993) Rice Production and Climate Change. In: Penning de Vries, F.W.T., et al., Eds., Systems Approaches for Agricultural Development, Kluwer Academic Publishers, Dordrecht, 175-189. https://doi.org/10.1007/978-94-011-2840-7_10

[51] Matthews, R.B., Kropff, M.J. and Bachelet, D. (1995) Introduction. In: Matthews, R.B., Kropff, M.J., Bachelet, D. and van Laar, H.H., Eds., Modeling the Impact of Climate Change on Rice Production in Asia, Cab International and International Rice Research Institute, Los Banos, 3-9.

[52] Dias, M.P.N.M., Navaratne, C.M., Weerasinghe, K.D.N. and Hettiarachchi, R.H.A.N. (2016) Application of DSSAT Crop Simulation Model to Identify the Changes of Rice Growth and Yield in Nilwala River Basin for Midcenturies under Changing Climatic Conditions. Procedia Food Science, 6, 159-163. https://doi.org/10.1016/j.profoo.2016.02.039

[53] Kim, H.Y., Horie, T., Nakagawa, H. and Wada, K. (1996) Effects of Elevated $\mathrm{CO}_{2}$ Concentration and High Temperature on Growth and Yield of Rice. II. The Effect of Yield and Its Component of Akihikari Rice. Japanese Journal of Crop Science, 65, 644-651. https://doi.org/10.1626/jcs.65.644

[54] Tashiro, T. and Wardlaw, I.F. (1989) A Comparison of the Effect of High Temperature on Grain Development in Wheat and Rice. Annals of Botany, 64, 59-65. https://doi.org/10.1093/oxfordjournals.aob.a087808

[55] Biswas, J.C., Sarker, U.K. and Sattar, S.A. (2001) Performance of Some BRRI Varieties Planted Year-Round. Bangladesh Rice Journal, 10, 55-59.

[56] Figueiredo, N., Carranca, C., Trindade, H., Pereira, J., Goufo, P., Coutinho, J., Marques, P., Maricato, R. and Varennes, A. (2015) Elevated Carbon Dioxide and Temperature Effects on Rice Yield, Leaf Greenness, and Phenological Stages Dura- 
tion. Paddy and Water Environment, 13, 313-324.

https://doi.org/10.1007/s10333-014-0447-x

[57] Horie, T., Matsui, T., Nakagawa, H. and Omasa, K. (1996) Effects of Elevated $\mathrm{CO}_{2}$ and Global Climate Change on Rice Yield in Japan. In: Omasa, K., Kai, K., Taoda, H., Uchijima, Z. and Yoshino, M., Eds., Climate Change and Plants in East Asia, Springer, Berlin, 39-56. https://doi.org/10.1007/978-4-431-66899-2_4 